\title{
A Philosophy of Communication
}

\author{
by James C. Kelly
}

\section{Methodology}

There are many philosophies. It is as well then at the outset to state what is meant by philosophy in this paper*.

Philosophy here is a critical realism ${ }^{1}$. Such a philosophy starts from the relevant data which must be carefully ascertained and utterly respected. The data of consciousness, which include but are wider than the date of the senses, are the most accessible to the philosopher. However the philosopher is not an isolated monad but a social being. So, data for philosophizing is drawn also from the kind of shared knowing we call 'common sense' and from all the other kinds of knowing which we call natural and human science, mathematics, history, art and literature, theology, religious experience and so on.

A word of warning must be uttered immediately. No one philosopher can cope nowadays with all the data of the real world; not to speak of trying to explain them. The proliferation of data, the growth of knowledge, has forced us into specialization. So, we have philosophers of knowledge, of science, of man, of God, of ethics, of hermeneutics and so on. Nowadays, although philosophers endeavour to have a professional generalist's grasp of philosophical conclusions outside their own proper field - and although there is overlapping between fields - an all-embracing detailed philosophy does not exist in any one head.

Philosophers then give their concentrated attention to the relevant data; neither adding anything nor taking anything away. When they strive to perceive the data and search for a form of words to express what has been perceived they use the method (not necessarily the ontology) of the phenomenologist. That is to say, they will labour to arrive at a formulation or description which is so clear and complete that any person of good will (who has perceived the data, reflected upon them and who understands the words) will accept and acquiesce.

Attention to the data is only the beginning. Philosophers contemplate and reflect on the data. They seek an understanding. That is to say they seek an explanatory, intelligible pattern of relations, connections or disconnections, between parts or articulations or aspects of the data. Likewise they will seek relationships between various sets of data.

However an understanding is not enough. Philosophers seek the understanding, the fully reasonable understanding. They must satisfy themselves that all the relevant questions have been asked and answered. They try to discover not merely what can be intelligently grasped but also what can be reasonably affirmed ${ }^{2}$. Only when they have checked and rechecked all the available evidence (not merely in their own but against other minds) can they decide and affirm 'it is so!' As far as humanly possible they have grasped and known reality.

Dr. James C. Kelly, SJ, ist Professor für Philosophie am Milltown Institute of Theology and Philosophy in Dublin, Irland. 
This method of philosophizing has been called the 'generalized empirical method'3.

The structured form of knowing just outlined is clearly applicable when trying to analyse and understand the data of consciousness. The same method, which is invariable, is used in striving to understand the data of common sense and the data of all the other modes of human knowing. The term 'data of consciousness' is applied to our experience of psychic activity as such; as opposed to 'data of the senses'. However the term is applicable, of course, to all human knowing in all its modes.

Common sense, the sciences, the arts, theology, all modes of human knowing have their own particular method. These methods are autonomous and philosophers must respect the autonomy. Each mode of knowing, by means of its own specific use of intelligence, arrives at its own particular aspects of reality, its own realm of being, its own particular world. The philospher's task is not to teach the scientist science nor to meddle in the rapid, pragmatic insights of common sense. Philosophers have differnt work to $\mathrm{do}^{4}$.

By means of each different mode of cognition we know different partial aspects of the world. Common sense as such knows nothing of the sciences. The sciences go beyond and beneath common sense and sometimes seem even to contradict it. The poet may know nothing of the distinct worlds of the historian and the mathematician. Apparent contradictions between different aspects of the world can be resolved once the different types of knowing are recognized.

The primary task of philosophers is to attempt an integration of the many and different forms of human knowing. They attempt this in the knowledge that all modes of human knowing are complementary, not to be confused with one another, and all necessary (although not all in one head) to build up an over-all view of the universe. This primary task of integration is positive ${ }^{5}$.

Philosophers may have negative tasks to perform also. Every mode of human knowing can deviate from its proper and particular method. A historian can abandon a proper objectivity and espouse the more consoling popular prejudices of common sense. A theologian (failing to consult historians or exegetes) may build a whole theory on misinterpreted texts. People, believing themselves safely within their own proper fields, ask questions, attempt solutions, make extrapolations and assertions that are in fact outside their proper brief or charter, beyond the capacity of their particular methods or instruments to achieve. Modes of knowing can be unwittingly employed in realms of reality where they have no competence. The positivist who tries to explain religious experience is an example. Art is deformed when it is instrumentalized crudely to be didactic.

The philosopher must not try to impose a philosophical method on the scientist who is doing science, on the artist who is doing art and so on. Philosophers however must try to perceive various deviations from proper method in the different realms of human knowing. Philosophers must then endeavour to persuade scientists, artists, theologians, historians, men and women of common sense, and so on, to reorientate their proper specialized mode of knowing and of discovery so that reality may be properly known in all its aspects.

That is what I mean by philosophy. 


\section{Philosophy of communication}

A philosophy of communication then must attend to the relevant data on which it will reflect in a search for critical understanding.

The data of consciousness must be included in the reflection. In our waking hours, when we are in the company of people and perceived by them, we are trying to communicate, communicating or failing to communicate all the time. Very many, although not all, of our dreams are about communication ${ }^{6}$.

A phenomenologist method of careful observation, critical analysis and exact formulation is needed to render an account of the data of consciousness or of any other data. There is no doubt that such a method can be greatly helped by familiarity with the most important literature, drama, cinema and art.

The method employed must take into account very seriously the findings of human scientists: psychologists, social psychologists, anthropologists, sociologists and, in particular, those human scientists who have specialized in the study of interpersonal and mass communication.

Scientific research into communication is (and perhaps always will be) incomplete. Further research will be carried out with better instruments and further questions will arise for the philosopher to ponder over. Even at present however it seems clear that we are sure enough of the main features of the communication process to make possible the construction of an enlightening and verifiable model of that process.

For example, it happens that the last empirical details of some situation or event have not been scientifically determined: 'do people read all the books they borrow from a library?' Or, the exact significance of a set of statistics has not been verified or is unverifiable at the moment.

That however does not mean that all is lost. The human scientist is dissatisfied. But enough can be known - short of scientific certainty - about the situation, event or statistics for a philosopher to decide that a contingent tendency, drive, deviation or aberration must be taken into account as a possibility if a complete framework or frame of reference is to be formed within which the process of communication can be understood.

\section{Interdisciplinarity}

Clearly then philosophers' investigation of communication has to be interdisciplinary. It is not easy to be interdisciplinary in a satisfactory way. It is necessary to be sufficiently familiar with literatures, arts, areas of philosphical investigation other than one's own, theologies, religion and so on. In particular philosophers must read sufficiently in different branches of the human sciences.

Different disciplines have their particular viewpoints, methods, languages. Philosophers must learn the technical languages. They must also perceive and respect the specific viewpoints and methods - in so far as they are justified - as neccesary and autonomous.

Philosophers must then try to understand, from a philosophical point of view, the insights grasped by non-philosophical modes of investigating and knowing. Philosophers must try to be unifiers, integrators and when necessary re-orientating critics. 
What philosophers of communication try to do is likely not to be well received by human scientists. Even though philosophers respect the autonomy of human science, they are still likely to be seen by scientists as interlopers. The dismayed human scientists, rightly situated in their own proper viewpoint, and operating according to their own proper method, are likely to find the philosophical viewpoint unintelligible and the philosophical method at least distasteful. In practice, philosophers can only grin and bear it ${ }^{7}$.

\section{Aim of a philosopby of communication}

The direct aim of philosophy of communication is not the making of a better communicator in practice. To become a good communicator various attitudes and skills are required. Acquiring or teaching those skills is a different discipline from a philosophy of communication. Unterstanding and acquiring the skills of communication belongs to a discipline called 'communication arts'. There is no attempt at a full treatment of communication arts in this paper; such a treatment lies outside my scope.

However, in practice, a philosophy of communication is indirectly useful. It can provide a useful mental background from which communication can be planned. It can save a would-be communicator from exaggerated expectations and subsequent disillusionment ${ }^{8}$.

The direct aim of a philosophy of communication is to understand the whole process of communication. It is an effort to understand how and why communication succeeds or how and why it fails. The success or failure may be total or partial.

A philosophy of communication should help one to recognize some theories (i.e. early deterministic behaviourism) as thoroughly unsatisfactory and others (i.e. the basically publicist minor determinism of Marshall McLuhan) as confused and misleading 9 .

\section{Pbilosophers}

Not a few philosophers touch upon the problem of communication. However what they have to say on this subject is usually too implicit, too unsystematic, too partial or too conceptualist.

Older philosophers were of course hampered by their lack of the dimension given by the modest success of our contemporary psychology and sociology. Even St Thomas Aquinas in his article De Magistro is unsatisfactory today ${ }^{10}$. His concepts are impeccable and his logic exact but he lacks perforce the grip on the singular and the empirical which we demand of a contemporary philosophy.

Modern philosophers like the early Ayer ${ }^{11}$, Wittgenstein ${ }^{12}$, the structuralists ${ }^{13}$, Chomsky ${ }^{14}$, the philosophers of language ${ }^{15}$, are too partial in their approach. They deal almost exclusively with the communicative sign. What they have to say is often of great interest but it is not nearly a total philosophy of communication. These philosophers can be powerful to arouse initial interest in the problem of communication and, as well, they can provide a method for achieving the final step in interpretation. I find they tend, however, rather to neglect the middle ground: the questions one must ask about the whole process from perception to interpretation. 
Two philosophers have dealt directly nd fairly systematically with communication. They are Alfred Schutz (the Austrian phenomenologist and friend of Husserl) and Bernard Lonergan, the Canadian Jesuit, philosopher and theologian ${ }^{16}$ and 17 . Schutz and Lonergan agree with and complement one another. Suzanne Langer, the phenomenologist disciple of Ernst Cassirer, has gone further than Schutz and Lonergan in working out what symbols are and how one kind of symbol communicates ${ }^{18}$. These are the philosophers I attempt to follow in constructing my model.

One version of the sociology of knowledge, represented by Peter Berger and Thomas Luckmann, draws heavily on Schutz's insights ${ }^{19}$. This kind of macrosociology is not easily distinguished from a philosophy.

\section{Elements of the problem}

Communication is sharing meaning.

This statement seems to be as incontrovertible as it is obvious. I arrived at the statement first about ten years ago after meditating on a sentence from Bernard Lonergan's Method in Theology: 'A community . . . is an achievement of common meaning'20. The statement needs to be explained and explaining the proposition 'Communication is sharing meaning' is the whole task of a philosophy of communication.

A slightly different proposition is also true: 'Communication is sharing nonmeaning'. Here 'non-meaning' signifies non-sense or error. Error and nonsense are certainly communicated and indeed very successfully.

To explain or understand these propositions it is necessary to ask the following questions and look for answers.

a) What is 'meaning'? From Plato on philosophers have asked this question at least implicitly. I do not see the discovery of meaning - which must precede any attempt to share meaning - as merely taking a look at something outside. The discovery of meaning is a structured process. It is a process which involves necessarily being attentive, reflective, intelligent, reasonable and, finally, being responsible in judgment. This is the structured process of knowing and what is finally judged to be known is precisely meaning. Meaning is then interior to the knower. Because of this inferiority, some material or corporeal means must be found to manifest meaning (the fruit of hidden psychic activity) to others with whom it is desirable to share it.

b) What is 'sharing'? In this context, investigation leads us to consider carriers of meaning: the means by which a meaning is offered to another.

Here I follow Alfred Schutz's analysis of marks, indications, signs and symbols. This treatment helps one to see that perception or apperception of a material object or event (which is the carrier of meaning) is both necessary and irrelevant. I say necessary because only something perceptible can bridge the gap between two psyches. I say irrelevant because carriers of meaning are not designed to give understanding of the material object or event which they themselves are. They are designed to lead to understanding something else. That is what is meant when we say the specific function of carriers of meaning is appresentational rather than perceptual. The function transcends the material object or event which is perceived. 
By means of carriers of meaning one is enabled to transcend the limitations of the Self, to reach out and explore the multiple finite provinces of meaning by which reality is mediated.

c) Who are they who try to communicate and how do they operate in the process? What are the possibilities and limitations in concrete persons that affect their carrying out of the process of sharing meaning? This leads to an examination of commonplace findings in empirical and social psychology about cognition and motivation and an analysis of human science research in mass-media communication. These two considerations are the basis for philosophizing about, what we shall call (in Lonergan's words) 'individual', 'dramatic' and 'group biases'; their social effects and the possibility of their reversal.

d) From a consideration of the foregoing analysis, is it possible to form an over-all plan to encourage and improve the quality of communication? My affirmative answer - both modest and cautious - leads to 'An overall plan for communication'. Here we have to consider (again using Lonergan's terms) the 'general bias of common sense' and, its social consequence, the 'longer cycle of decline' which is difficult to reverse. The kind of knowing we call 'common sense' has a tendency to be unquestioning, inert, stagnant. This stagnant inertia tends to obtrude itself into other modes of human knowing. Human knowing then can and does deteriorate; as knowing deteriorates so too does communication. An overall plan for communication then must be built, first of all, on a re-education which fosters a critical awareness of and a practical understanding of the modes of human knowing.

\section{The everyday world}

That is why it is important, before attempting to answer the four questions explicitly, to consider, in the first place and at some length, a philosophy of the everyday world. That involves a consideration of everyday knowing which is common sense and a philosophy of everyday communication.

A sufficiently hard philosophical analysis of everyday life is necessary because a great deal of our daily knowing and communication happens within the world of common sense. In addition, whether the meaning to be shared is on the level of everyday common sense or on some of the higher levels of science, art, philosophy, theology or religion, the carriers of meaning, the communicative signs are always and of necessity in the world of immediacy; that is, the world of sensation, the world which is the source of data for common sense ${ }^{21}$. I have read some accounts of the communication process which were ultimately unsatisfactory because the writers were far too unaware that the everyday world is only one of the aspects of the real world in which we live and communicate. These writers had not sufficiently differentiated their consciousness.

To analyse the world of daily life philosophically is to begin to differentiate one's consciousness. That is to say, it is to begin to be aware of and to recognize different forms or modes of human knowing and, consequently, of human communication. These forms or modes of human knowing and communicating grasp and endeavour to share different modes of meaning, different aspects or realms of reality, different worlds; all of which are desirable and necessary aspects of the real world, none of which must be confused with any of the others ${ }^{22}$. 
Differentiated consciousnesses are not common. Yet today, when we are inundated with views, opinions, convictions of all shapes, sizes and colours (conveyed to us by highly sophisticated means), the differentiation of consciousness is urgently necessary. Undifferentiated consciousness is likely to result in an inert, unquestioning, stagnant common sense which can infect all other modes of human knowing. Inadequate and uncritical knowing leads necessarily to inadequate communication. That is why, in any overall plan for safeguarding communication, I see re-education in a proper method of knowing as fundamental.

\section{Footnotes}

I have been teaching a course in the philosophy of communication for the last eight years. The course occupies a little more than one third of the academic year and is part of 'philosophy of knowledge' and epistemology.

About 1979, Frs. Robert A. White, S.J. (Director of Research) and Stefan Bamberger, S.J. (General Director) of the Centre for the Study of Communication and Culture in London (CSCC, 221 Goldhurst Terrace, Hampstead, London NW6 3EP) asked me to write at length on the philosophy of communication. With considerable misgiving, I agreed. The book was to be one in a series of monographs planned and in preparation by the Centre. However when I had finished writing it became apparent that my work was more suitable for a series called 'Reports and Studies': long 'working-papers' published by the Centre.

My long paper is, I hope, only a beginning. Its nature is that of a university 'text-book' and it is better read in a situation where discussion and dialogue are possible. I wrote it with my stable 'audience', my students, in mind. Pedagogically, over the years, my method has been satisfactory.

1 This is the type of philosophy practised by Bernard Lonergan. Insight: a study of human understanding. London: 1967. (7th student's edition). Method in Theology. London: 1972.

2 Bernard Lonergan. Insight. Chapter 14, sec. 2, p. 391.

${ }^{3}$ Ibid. Chapter 7, sec. 9, p. 243.

${ }^{4}$ Ibid. Chapter 14 , sec. 4.5 , pp. 423-430.

5 Ibid. Chapter 14, sec. 2 and 3, pp. 398-399.

${ }^{6}$ Ibid. Chapter 6, sec. 2.5 and 2.3 , pp. 187 and 184.

7 Ibid. Chapter 14, sec. 4.6, pp. 423-430.

${ }^{8}$ Krech, Crutchfield and Ballachey. Individual in Society. London, N.Y.: 1962. International Student Edition. P. 23.

${ }^{9}$ Herbert Marshall McLuhan. The Meaning is the Massage. Penguin. This short book is the best outline of McLuhan's ideas.

${ }^{10}$ De Veritate. Q.XI. De Magistro, art 1. 'Utrum homo docere alium possit et dici magister, vel Deus solus?'

11 A.J. Ayer. Language, Truth and Logic. London: 1967. Cf. Men of Ideas. British Broadcasting Corporation: 1978. This is the expanded text of Brian Magee's interviews with 15 philosophers. Ayer, pp. 118-133.

12 Ludwig Wittgenstein. Philosophical Investigations. Oxford: 1963. Cf. Men of Ideas, pp. 98-115.

${ }^{13}$ Philip Petit. The concept of structuralism. Dublin: 1975. 
14 Noam Chomsky. Aspects of the theory of syntax. Massachusetts: 1967. Df. Men of Ideas. pp. 204-223.

15 John R. Searle. Speech Acts: an essay in the philosophy of language. London: 1970. Cf. Men of Ideas, pp. $182 \mathrm{ff}$.

16 Alfred Schutz. Collected Papers. 3 volumes. The Hague: 1973.

17 Bernard Lonergan. Cf. note 1.

18 Suzanne Langer. Feeling and Form. London: 1953. Philosophy in a new key. Harvard and London: 1957.

19 Peter Berger and Thomas Luckmann. The social construction of reality: a treatise in the sociology of knowledge. London: 1971. Berger and Luckmann freely admit their debt to Alfred Schutz: cf. note 16.

20 Bernard Lonergan. Method in Theology. Darton, Longman and Todd: London: 1972. Part 1, chapter 3, sec. 8 , p. 79 .

21 Alfred Schutz. op. cit. Volume 1, pp. $321 \mathrm{ff}$.

22 Bernard Lonergan. Method in Theology. Pp. $303 \mathrm{ff}$.

\section{ZUSAMMENFASSUNG}

Es gibt viele Philosophien. Deswegen ist es gut zu sagen, was hier unter Philosophie verstanden wird. Sie wird hier verstanden als kritischer Realismus. Eine solche Philosophie beginnt mit den gegebenen Daten, die respektiert werden müssen. Die Daten des Bewußtseins - welche weiter sind als jene der Sinne, sie aber mit beinhalten - sind für den Philosophen am besten zugänglich. Aber er ist keine Monade. Er muß deswegen alle anderen Lebensbereiche des Menschen mit berücksichtigen. Dabei ist klar, daß kein Philosoph alle Gegebenheiten unserer heutigen Welt voll berücksichtigen kann ... Aber die Beachtung der gegebenen Daten ist nur der Anfang. Die Philosophen betrachten diese Gegebenheiten und denken über sie nach, suchen diese einzeln und in ihren Zusammenhängen besser zu verstehen. Dabei ist nicht irgend ein Verstehen genug, es geht um das Verstehen. Erst nach sorgfältiger Arbeit stellen sie dann fest: es ist so. Diese Methode wird als die generalisierende empirische Methode bezeichnet. Sie gilt besonders, wenn es um Dinge des menschlichen Bewußtseins geht. Hauptaufgabe des Philosophen ist die Integration der verschiedenen Formen menschlichen Wissens und menschlicher Erfahrung, wobei die einzelnen Wissenschaften als solche durchaus in ihrer Eigenständigkeit respektiert werden müssen.

Eine Philosophie der Kommunikation muß alle Daten der verschiedenen Wissenschaften berücksichtigen, aber dann kann sie schon dort Aussagen machen, wo die exakte Wissenschaft noch nicht zufrieden ist. So mögen z.B. Informationen über den Buchverleih einer Bibliothek solche Wissenschaftler noch nicht voll befriedigen. Aber der Philosoph kann aus einem Teil dieser Daten schon eine Tendenz, einen Irrweg oder auch den Kern einer Entwicklung ablesen. Selbstverständlich muß eine solche Philosophie interdisziplinär grundgelegt sein. Eine Philsosophie der Kommunikation ist kein Ersatz für eine Fachausbildung. Für die Praxis ist eine Philosophie der Kommunikation nur indirekt nützlich, indem sie den Hintergrund aufhellt, auf dem Kommunikation geplant werden kann: So können falsche Erwartungen verhindert und Enttäuschungen abgebaut werden.

Direktes Ziel einer Kommunikationsphilosophie ist das bessere umfassendere Verständnis des Kommunikationsprozesses als solchen.

Verschiedene Philosophen haben das Gebiet Kommunikation erwähnt, aber was sie sagen, ist meistens zu implizit, zu unsystematisch und bruchstückhaft. Den alten Philosophen fehlt oft - einschließlich Thomas von Aquin in seinem „De Magistro“ - die konkrete heutige 
fehlt oft - einschließlich Thomas von Aquin in seinem „De Magistro“ - die konkrete heutige Erfahrung als Ausgangspunkt. Zwei moderne Philosophen haben sich unmittelbar mit dem Thema befaßt, Alfred Schutz und Bernard Lonergan. Susanne Langer, Phänomenologin und Schülerin von Cassirer, ging noch weiter als Schutz und Lonergan.

Wenn man versucht, die Elemente des Problems aufzulisten, dann muß man zunächst feststellen, daß Kommunikation der Austausch von Meinungen ist. Dies zu erklären ist Aufgabe einer Kommunikationsphiolosophie.

Meinung ist ein strukturierter Vorgang, der der Erklärung bedarf. Was weiter heißt dann Mitteilen (Sharing) und dann die Frage nach jenen, die Kommunikation betreiben: Wer sind sie und was können sie innerhalb welcher Grenzen? Es ist die Frage zu stellen nach der individuellen, der dramatischen und der Gruppeneinstellung (Lonergan). Kann man dann von diesen Voraussetzungen aus zu übergreifendem Verständnis kommen, was die Qualität von Kommunikation verbessert? Nur eine gesunde allgemeine Philosophie des menschlichen Lebens kann Grundlage auch einer guten und realistischen Kommunikationsphilosophie sein. Eine philosophische Analyse unserer täglichen Welt hilft, in unserem Bewußtsein zu unterscheiden. Das ist der Anfang menschlichen Wissens und damit auch menschlicher Kommunikation ... .

\section{RÉSUME}

Une philosophie de la communication doit tenir compte des données des différentes sciences. Alors, elle peut déjà apporter des témoignages là où la science exacte les refuse encore. A partir de données, le philosophe peut déjà dégager une tendence, une fausse voie ou également le noyau d'un développement. Le but direct d'une philosophie de la communication est la meilleure et la plus complète compréhension du processus de communication. Deux philosophes modernes ont examinés de près ce sujet: Alfred Schutz et Bernard Lonergan. A eux vient s'ajouter encore Susanne Langer. La philosophie de la communication vient principalement déclarer la communication un échange d'opinions. On recherche ce qu'il faut communiquer et à qui il faut le communiquer. Seule une philosophie générale saine peut être également la base d'une bonne philosophie réaliste de la communication.

\section{RESUMEN}

Una filosofia de la comunicación social debería tener en cuenta los datos de las diversas ciencias. De ests modo podría pronunciarse sobre aspectos a los que todavía no llegan las ciencias exactas. A base de los datos de otras ciencias, la filosofia puede descubrir una tendencia, un camino erroneo o el núcleo de una evolución. El objeto propio de una filosofia de la comunicación es una comprensión mejor y más amplia del proceso de la comunicación social. Dos filósofos modernos se ocuparon directamente del tema, Alfred Schutz y Bernard Lonergan, a los que hay que añadir Susanne Langer. La filosofia de la comunicación busca sobre todo explicar la comunicación social como intercambio de opiniones. Se pregunta sobre lo participado y los participantes. Solo una sana filosofia general de la vida humana puede ser base para una filosofia, buena y realista, de la comunicación social. 